\title{
Phytochemical Screening of Leaf Extracts of Eleven selected Tropical Plants Species from Eastern and Southern Nigeria
}

\author{
*NWANDU, CJ; NYANANYO, BL; OZIMEDE, CO
}

\author{
Department of Plant Science and Biotechnology, University of Port Harcourt, Choba, Port Harcourt, Rivers State, Nigeria \\ *Corresponding Author Email: joy.nwandu@yahoo.com; Other AuthorEmails: bionyananyo@yahoo.com, ozimedechristian@yahoo.com
}

\begin{abstract}
The pyhtochemical constituents of butanol and acid leaf extracts of eleven (11) plant species from three different families (Annonaceae, Apocynaceae and Euphorbiaceae) obtained from various locations in eastern and southern Nigeria were made following standard techniques. Results obtained show that the leaf extracts contain alkaloids, flavonoids and saponins. This paper provides evidence that alcoholic and acid leaf extract of the selected plant species studied contains medicinally important metabolites that justifies their usage as traditional medicine for treatment of various ailments.
\end{abstract}

DOI: https://dx.doi.org/10.4314/jasem.v23i10.16

Copyright: Copyright (C) 2019 Nwandu et al. This is an open access article distributed under the Creative Commons Attribution License (CCL), which permits unrestricted use, distribution, and reproduction in any medium, provided the original work is properly cited.

Dates: Received: 01 August 2019; Revised: 23 October 2019; 27 October 2019

Keywords: Tropical plants, Phytochemicals, Ethno-medicine, Extracts

Plants form an integrant part of life on earth, humans and animals depend on them (Davis and Heywood, 1973 Okujagu., 2008). They are essential resources for human wellbeing and are essential as food, clothing, medicine, rubber, timber and Shelter. Plants produce chemical compounds for self-defense. Plant value is based primarily on its phytochemicals. Some of these phytochemicals are confirmed effective therapeutic agents for various diseases (Anyadele and Adebiyi, 2007; Jack and Okorosaye-Orubite, 2008) while some exhibit inhibitory effect on microbial growth or act synergistically with other agents against microorganisms (Ogbeche et al., 1997; Okerelu and Ani, 2001; Alinor, 2006). Plants largely have diverse chemical compositions depending upon species. A respectable number of plants have been identified to be of medicinal and economic value. Plants that are of medicinal value are frequently used as herbal remedy for the rebuilding and maintenance of good health (Gayathri and Kiruba, 2014). Some herbs have been considered as drugs and therefore generally safe and effective (Uboh et al., 2010). Phytochemicals are basically grouped into primary and secondary metabolities (Kumar et al., 2009; Parekh and Sumitra, 2007). Phytochemicals are defined as bioactive nonnutrient plant compounds found in fruits that have been attributed to reduce the risk of major chronic diseases (Blessy et al., 2012). The main components of phytochemical comprise of carbohydrates, aminoacids, proteins, and chlorophylls, while, secondary metabolites consist of alkaloids, saponins, steroids, flavonoids, tannins, etc.( Kumar et al., 2009). The phytochemical constituents play an important role in the identification of crude drugs and also to evaluate drugs obtained from the plant sources (Moses et al., 2013). Ethnomedicinal study deals with the study of traditional medicines. Since ancient times mankind has been using herbal plants, organic materials as well as materials from the sea, rivers etc. for its betterment. These substances have been used as food, medicine etc. Amongst them, the substances having medicinal value have been broadly used for discussing several disease conditions. Herbs being easily available to human beings, have been explored to the maximum for their medicinal properties. Various parts of the plants like roots, leaves, bark, exudates etc. are used as per medicinal properties (Perumal and Gopala 2007). Phytochemicals are non-nutritive plant substances with defensive potentials and can prevent diseases. Phytochemistry is involved with chemicals derived from plants (Harborne 1973). Techniques in phytochemistry are extraction, segregation and elucidation of plant substances together with some chromatographic techniques MPLC, HLPC, LC-MS (Stace, 1980). The discipline is essential for Pharmacognosy or detection of new plant related drugs for physiological studies. Avariety of chemicals such as Flavonoids, Alkaloid, Tannins and Saponins can be isolated from plants. Therefore the objective of this paper is to present the report of a preliminary phytochemical assay of butanol and acid leaf extracts of eleven (11) plant species from three different 
families (Annonaceae, Apocynaceae and Euphorbiaceae) obtained from different locations in eastern and southern Nigeria.

\section{MATERIAL AND METHODS}

Chemicals: The following chemicals and reagents were used for the research ; Concentrated acetic acid, Distilled water, Absolute n-butanol, Absolute methanol, Absolute ethanol, Ammonium hydroxide, $17 \%$ sodium carbonate, Acetone, Tannic acid standard, Folin-Denis Reagents, Sodium carbonate, Forrestal and BAW.

Collection: Plant samples were obtained from the fresh living parts of the plants in some local government areas in Abia, Enugu, Imo and Rivers States. Samples were collected in dark polyethylene bags and preserved using the plant press before taking to the herbarium for identification and authentication.

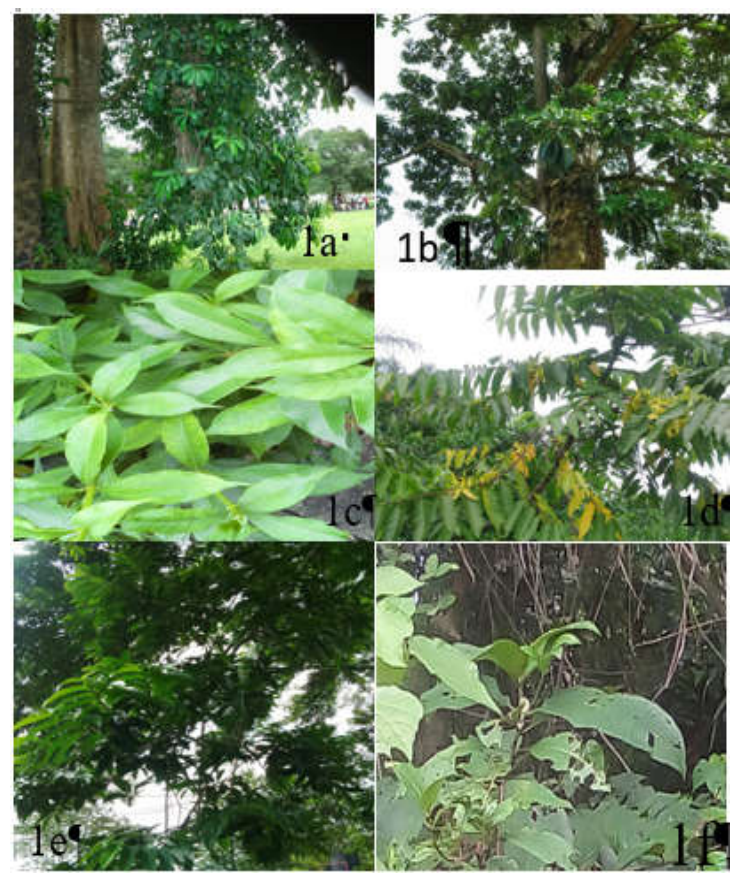

Plate 1a-1f: (1a) Alstonia bonnei De Wild, (1b) Alstonia congensis Engl, (1c) Allamanda cathartica Linn, (1d) Cananga odorata (Lam.) Hook .F and Thomson, (1e) Cleistopholis patens (Benth.) Engl and Diels, (1f) Funtumia africana (Benth.) Stapf

Identification of Plant Materials: The plant samples identification (Plate 1a-j) were done in the herbarium of the Plant Science and Biotechnology Department, University of Port Harcourt and authenticated at the Forest Research Institute of Nigeria. Sets of voucher samples were also deposited in Forest Research Institute of Nigeria Herbarium and given specimen numbers and another set at the Herbarium of the University of Port Harcourt in the Department of Plant science and Biotechnology
Extract Preparation: The leaves of fresh plant specimen were collected and crushed using a blender placed in a container, labeled accordingly using a masking tape and marker pen and kept in the refrigerator. This was to preserve the plant tissue until when they will be used.

Preliminary Qualitative Phytochemical Analysis: The leaf powder of the study plant was dissolved in different solvents and the preliminary phytochemical tests were carried out (Harborne, 1984)

Phytochemical investigation for tannins: This was achieved using three reagents namely; Tannic acid standard, Folin-Denis Reagents and Sodium carbonate and calculated as follows: If $\mathrm{C}=\mathrm{mg}$ tannic acid obtained from the graph for the plant material and soil extracts, then

$$
\text { Tanins }=\frac{(\mathrm{mg}) \times \text { extract volume }(\mathrm{ml})}{10 \times \text { alquot }(\mathrm{ml}) \times \text { sample } w t(\mathrm{~g})}
$$

Phytochemical investigation of alkaloids: Hsarborne (1973) method was used to investigate the alkaloids in the samples. Percent Alkaloid (ALK) was calculated as

$$
\% A L K=\frac{W_{F P R}-W_{E F P}}{W_{S}-1} \times 100
$$

Where $\mathrm{W}_{\mathrm{FPR}}=$ weight of filter paper and residue; $\mathrm{W}_{\mathrm{EFP}}$ = weight of empty filter paper and Ws $=$ weight of sample used

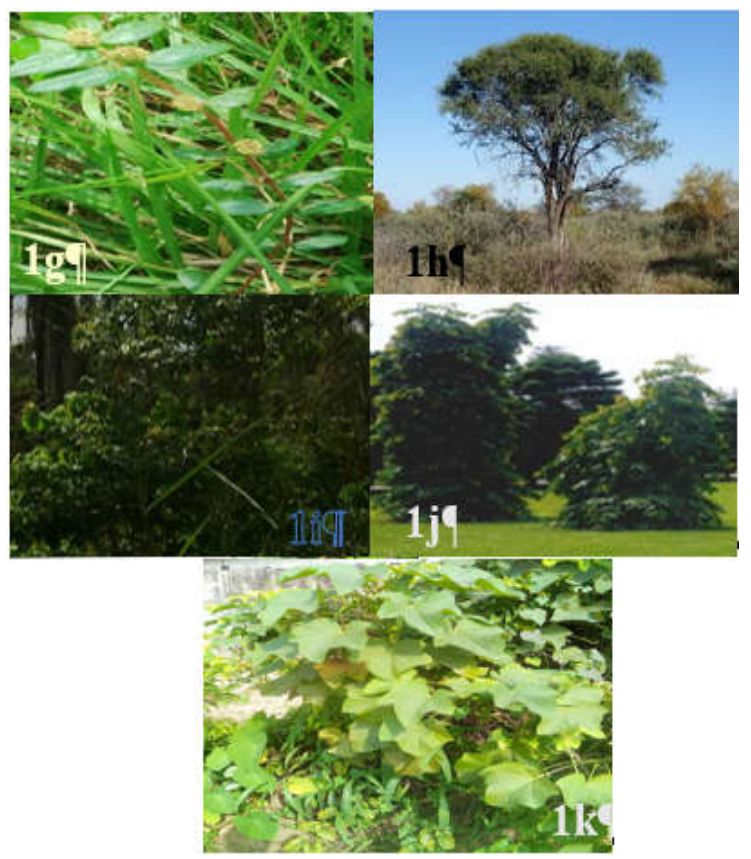

Plate 1g-1k: (1g) Euphorbia hirta Linn, (1h) Bridelia atroviridis Mull.-Arg, (1i) Bridelia ferruginea Benth, (1j) Polyalthia longifolia CV. Pendula, (1k). Jatropha curcas. L.. 
.Table 1: Data Collection

\begin{tabular}{|c|c|c|c|c|c|c|c|c|}
\hline $\mathbf{S} / \mathbf{N}$ & Names of Plant & Collection Location & Latitude & Longitude & Altitude & $\begin{array}{l}\text { Date } \\
\text { Colle }\end{array}$ & $\begin{array}{l}\text { of } \\
\text { ction }\end{array}$ & $\begin{array}{l}\text { Name of Collector } \\
\& \text { Collection No. }\end{array}$ \\
\hline \multirow[t]{2}{*}{1} & $\begin{array}{l}\text { Alstonia boonei } \\
\text { De Wild } \\
\text { (Apocynaceae) }\end{array}$ & $\begin{array}{l}\text { (a) Ofrima Uniport, } \\
\text { Obio/Akpor } \\
\text { Rivers State }\end{array}$ & $4.901^{\circ} \mathrm{N}$ & $6.923^{\circ} \mathrm{E}$ & $\begin{array}{l}13.20 \\
\text { meters }\end{array}$ & $\begin{array}{l}14^{\text {th }} \\
2017\end{array}$ & July, & 001 \\
\hline & & $\begin{array}{l}\text { (b) Umuezike Ofeme } \\
\text { Umuahia North } \\
\text { L.G.A, Abia State }\end{array}$ & $5.666^{\circ} \mathrm{N}$ & $7.422^{\circ} \mathrm{E}$ & 71 meters & $\begin{array}{l}17^{\text {th }} \\
2017\end{array}$ & July, & Chidinma Joy \\
\hline \multirow[t]{4}{*}{2} & $\begin{array}{l}\text { Alstonia congensis } \\
\text { (Apocynaceae) }\end{array}$ & $\begin{array}{l}\text { (a) Igwuruta } \\
\text { Obio/Akpor PH, } \\
\text { Rivers State }\end{array}$ & $4.944^{\circ} \mathrm{N}$ & $7.007^{\circ} \mathrm{E}$ & $\begin{array}{l}14.10 \\
\text { meters }\end{array}$ & $\begin{array}{l}12^{\text {th }} \\
2017\end{array}$ & July, & 002 \\
\hline & & $\begin{array}{l}\text { (b) UPTH Alakahia, } \\
\text { Obio/Akpor PH, } \\
\text { Rivers State }\end{array}$ & $4.889^{\circ} \mathrm{N}$ & $6.926^{\circ} \mathrm{E}$ & $\begin{array}{l}10.10 \\
\text { meters }\end{array}$ & $\begin{array}{l}14^{\text {th }} \\
2017\end{array}$ & July, & $\begin{array}{l}\text { Chidinma Joy } \\
003\end{array}$ \\
\hline & & $\begin{array}{lr}\text { (c) Umuoyo } \\
\text { Agbogugu, Awgu } \\
\text { L.G.A, Enugu }\end{array}$ & $5.863^{\circ} \mathrm{N}$ & $7.352^{\circ} \mathrm{E}$ & $\begin{array}{l}100 \\
\text { meters }\end{array}$ & $\begin{array}{l}17^{\text {th }} \\
2017\end{array}$ & July, & \\
\hline & & $\begin{array}{l}\text { (d) Ihube Okigwe, } \\
\text { Imo State }\end{array}$ & & & $\begin{array}{l}203 \\
\text { meters }\end{array}$ & $\begin{array}{l}17^{\text {th }} \\
2017\end{array}$ & July, & \\
\hline \multirow[t]{3}{*}{3} & $\begin{array}{l}\text { Allamanda } \\
\text { calhartica } \\
\text { (Apocynaceae) }\end{array}$ & $\begin{array}{l}\text { (a) Back of Ofrima } \\
\text { Uniport, PH Rivers } \\
\text { State }\end{array}$ & $4.904^{\circ} \mathrm{N}$ & $6.923^{\circ} \mathrm{E}$ & $\begin{array}{l}11.40 \\
\text { meters }\end{array}$ & $\begin{array}{l}12^{\text {th }} \\
2017\end{array}$ & July. & \\
\hline & & $\begin{array}{l}\text { (b) Allcaved Uniport } \\
\text { PH, Rivers State }\end{array}$ & $4.900^{\circ} \mathrm{N}$ & $\begin{array}{l}6.908^{\circ} \mathrm{E} \\
7.473^{\circ} \mathrm{E}\end{array}$ & $\begin{array}{l}4.50 \\
\text { meters }\end{array}$ & $\begin{array}{l}20^{\text {th }} \\
2017\end{array}$ & July, & $\begin{array}{l}\text { Chidinma Joy } \\
004\end{array}$ \\
\hline & & $\begin{array}{l}\text { (c) Amaogwugwu } \\
\text { Umuahia North, Abia } \\
\text { State }\end{array}$ & $5.633^{\circ} \mathrm{N}$ & & 30 meters & $\begin{array}{l}18^{\text {th }} \\
2017\end{array}$ & July, & \\
\hline \multirow[t]{3}{*}{4} & $\begin{array}{l}\text { Funtumia } \\
\text { Africana } \\
\text { (Apocynaceae) }\end{array}$ & $\begin{array}{l}\text { (a) Botanical Garden } \\
\text { Obio/Akpor PH, } \\
\text { Rivers State }\end{array}$ & $4.897^{\circ} \mathrm{N}$ & $6.916^{\circ} \mathrm{E}$ & $\begin{array}{l}12.80 \\
\text { meters }\end{array}$ & $\begin{array}{l}18^{\text {th }} \\
2017\end{array}$ & July, & \\
\hline & & $\begin{array}{l}\text { (b) Onyorie } \\
\text { Amechianaw, Enugu } \\
\text { South }\end{array}$ & $4.90365^{\circ} \mathrm{N}$ & $7.511^{\circ} \mathrm{E}$ & 80 meters & $\begin{array}{l}18^{\text {th }} \\
2017\end{array}$ & July, & $\begin{array}{l}\text { Chidinma Joy } \\
005\end{array}$ \\
\hline & & $\begin{array}{l}\text { (c) London Estate, } \\
\text { Umuebula } \\
\text { Etche, } \\
\text { Rivers State. }\end{array}$ & & & $\begin{array}{l}14.60 \\
\text { meters }\end{array}$ & $\begin{array}{l}1^{\text {st }} \\
2017\end{array}$ & August, & \\
\hline 5 & $\begin{array}{l}\text { Bridella } \\
\text { atrourride } \\
\text { (Euphorbiaceae) }\end{array}$ & $\begin{array}{lr}\text { UPTH } & \text { Alakahia } \\
\text { Obio/Akpor } & \text { PH, } \\
\text { Rivers State }\end{array}$ & $4.892^{\circ} \mathrm{N}$ & $6.927^{\circ} \mathrm{E}$ & $\begin{array}{l}9.30 \\
\text { meters }\end{array}$ & $\begin{array}{l}14^{\text {th }} \\
2017\end{array}$ & July, & $\begin{array}{l}\text { Chidinma Joy } \\
006\end{array}$ \\
\hline 6 & $\begin{array}{l}\text { Bridella } \\
\text { ferirrginea } \\
\text { (Euphorbiaceae) }\end{array}$ & $\begin{array}{l}\text { UPTH Alakahia } \\
\text { Obio/Akpor } \\
\text { Rivers State }\end{array}$ & $4.892^{\circ} \mathrm{N}$ & $6.927^{\circ} \mathrm{E}$ & $\begin{array}{l}7.70 \\
\text { meters }\end{array}$ & $\begin{array}{l}14^{\text {th }} \\
2017\end{array}$ & July, & $\begin{array}{l}\text { Chidinma Joy } \\
007\end{array}$ \\
\hline \multirow[t]{3}{*}{7} & $\begin{array}{l}\text { Euphorbia hirta } \\
\text { linn } \\
\text { (Euphorbiaceae) }\end{array}$ & $\begin{array}{lr}\text { (a) } & \text { Iriebe } \\
\text { Obio/Akpor, } & \text { PH } \\
\text { Rivers State } & \end{array}$ & $4.874^{\circ} \mathrm{N}$ & $7.107^{\circ} \mathrm{E}$ & $\begin{array}{l}19.20 \\
\text { meters }\end{array}$ & $\begin{array}{l}16^{\text {th }} \\
2017\end{array}$ & July, & $\begin{array}{l}\text { Chidinma Joy } \\
007\end{array}$ \\
\hline & & $\begin{array}{l}\text { (b) UPTH Alakahia } \\
\text { Obio/Akpor PH, } \\
\text { Rivers State }\end{array}$ & $4.892^{\circ} \mathrm{N}$ & $6.928^{\circ} \mathrm{E}$ & $\begin{array}{l}6.50 \\
\text { meters }\end{array}$ & $\begin{array}{l}14^{\text {th }} \\
2017\end{array}$ & July, & \\
\hline & & $\begin{array}{l}\text { (c) Chime Avenue } \\
\text { New Heaven, Nike } \\
\text { L.G.A, Enugu State }\end{array}$ & & & 78 meters & $\begin{array}{l}18^{\text {th }} \\
2017\end{array}$ & July, & \\
\hline
\end{tabular}




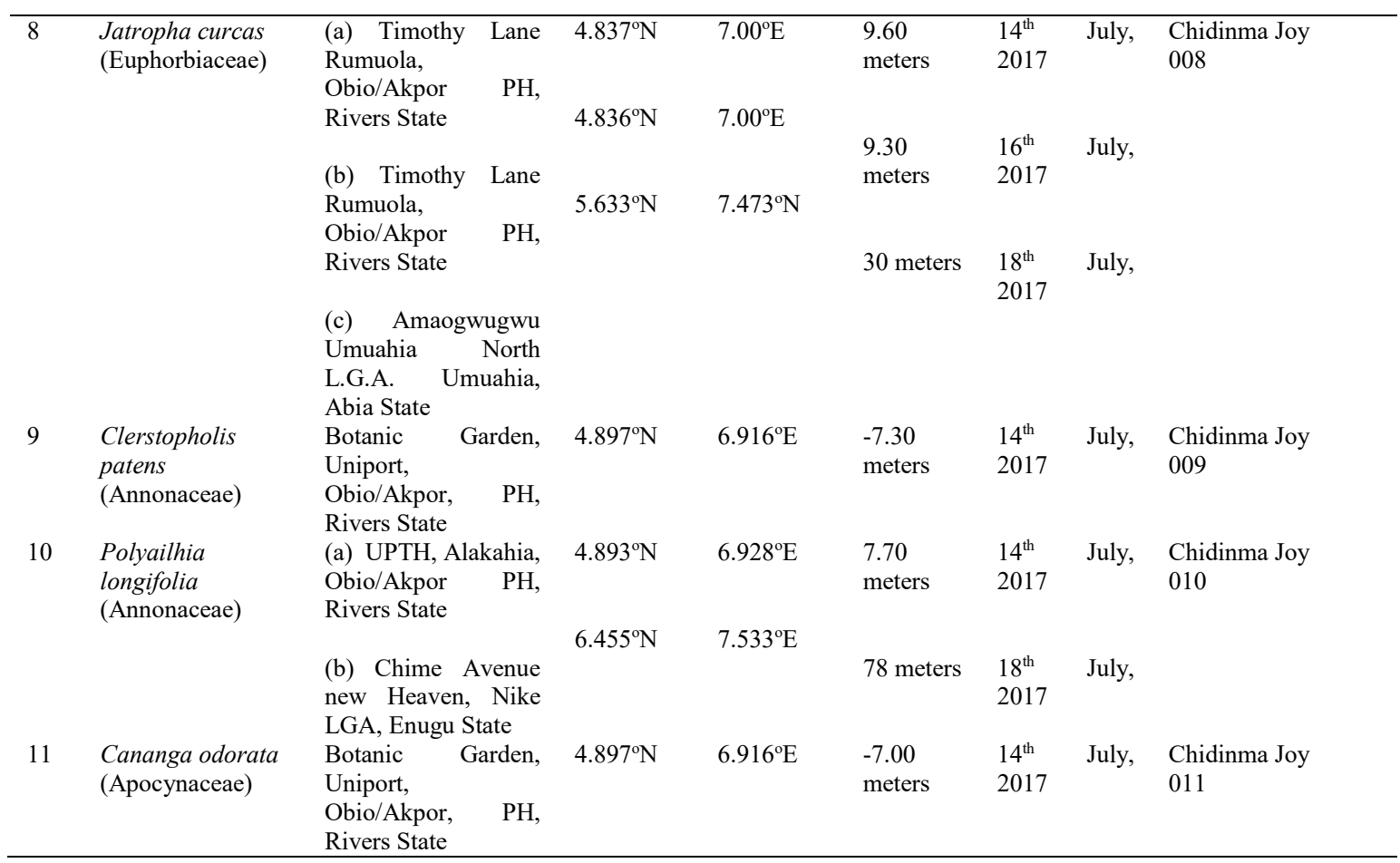

Phytochemical investigation of saponins A (2g) taster was introduced in a filter-paper and put into a soxhletextractor. Extractor was then put in a pre-weighed distillation flask, solvent added by means of the condenser. The set-up held in position with clamp. Cool water-jet was permitted to stream into the condenser and the hot solvent refluxed. The saponins in the solvent-chamber got removed in the course of unremitting refluxing, following complete saponins extraction, the condenser and the extractor were dis connected, the solvent evaporated for saponins concentration. The flask dried in oven to a stable weight and re-weighed to get precisely the saponins weight.

Phytochemical investigation of lipids: Exactly two grams $(2 \mathrm{~g})$ of sample was introduced into a filterpaper and positioned in extractor which was then left in a weighed distillation-flask. Acetone was deposited in the flask through the condenser linked to the extractor. The system was kept steady with a clamp. Water-jet was directed to the con denser and the hot solvent refluxed as the consequence of the lipid in the solvent- chamber was extorted in the course of incessant refluxing. When the lipid was noticeably extracted totally from test samples, the (condenser \& extractor) were detached; the solvent evaporated to strengthen the lipid. Then the flask was desiccated in oven to steady weight and measure again to achieve the weight of the lipid.
Phytochemical investigation of Flavonoids: About $1 \mathrm{~g}$ of the crushed leaf sample was weighted into eleven beakers and labeled accordingly about $5 \mathrm{ml}$ of absolute methanol was measured and put into beakers, stirred and left to stay for some minutes. Separation was performed by the aid of paper chromatography. Getting ready the chromatography paper precedes sample preservation. The chromatographic paper was obtained and the dimension measured. Spotting was done at a point known as the origin. Samples were collected one at a time using different capillary tube, for each individual sample and spotting directly along the origin at $2 \mathrm{~cm}$ away from each sample spot. The chromatographic tank contains the solvent-chamber and adjustable rods where the chromatography paper is hung to allow the solvent to travel. The various solvent used were; (i) BAW (n-Butanol-acetic acid and water: 4:1:5 (upper phase only) and (ii) Forrestal (acetic acid, hydrochloric acid \& water): 30:3:10.

\section{RESULTS AND DISCUSSION}

The preliminary phytochemical analysis of some of the tropical plants investigated in the study area were evaluated and results presented in table 2 .

Tannins: The result of this experimental work was drawn from the calculation of percentage of Tannin measured using a filter photo colorimeter. Alstonia congensis had the highest tannin while Allamanda cathartica has the lowest (figure 1). 
Table 2: Preliminary Phytochemical Analysis of some tropical plants

\begin{tabular}{|c|c|c|c|c|}
\hline S/No & Taxa & Alkaloid & Saponins & Tannins \\
\hline 1 & Alstonia boonei & ++ & ++ & ++ \\
\hline 2 & $\begin{array}{l}\text { Alstonia } \\
\text { congensis }\end{array}$ & ++ & ++ & +++ \\
\hline 3 & $\begin{array}{l}\text { Allamanda } \\
\text { cathartica }\end{array}$ & + & + & + \\
\hline 4 & $\begin{array}{l}\text { Funtumia } \\
\text { africana }\end{array}$ & ++ & + & ++ \\
\hline 5 & $\begin{array}{l}\text { Bridellia } \\
\text { artrourrides }\end{array}$ & +++ & +++ & ++ \\
\hline 6 & $\begin{array}{l}\text { Bridellia } \\
\text { ferriginea }\end{array}$ & ++ & ++ & ++ \\
\hline 7 & Euphorbia hirta & ++ & ++ & ++ \\
\hline 8 & Jatropha curcas & + & + & + \\
\hline 9 & $\begin{array}{l}\text { Cleistophilis } \\
\text { patens }\end{array}$ & + & ++ & + \\
\hline 10 & $\begin{array}{l}\text { Polyalthia } \\
\text { longifolia }\end{array}$ & + & ++ & + \\
\hline 11 & Canaga odorata & ++ & ++ & ++ \\
\hline
\end{tabular}

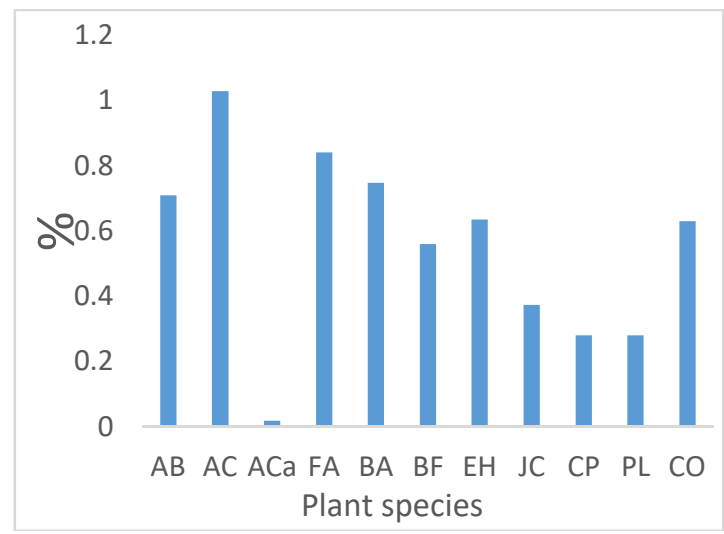

Fig 1: Percentage tannins content of the eleven plant species evaluated $(\mathrm{AB}=$ Alstonia boone $; \mathrm{AC}=$ Alstonia congensis, $\mathrm{ACa}=$ Allamanda cathartica $; \mathrm{FA}=$ Funtumia africana $; \mathrm{BA}=$ Bridellia Artrourrides; $\mathrm{BF}=$ Bridellia Ferriginea $; \mathrm{EH}=$ Euphorbia hirta $; \mathrm{JC}$ $=$ Jatropha curcas $; \mathrm{CP}=$ Cleistophillis patens $; \mathrm{PL}=$ Polyalthia longifolia $; \mathrm{CO}=$ Canaga odorata $)$

Alkaloid: The result for alkaloid was obtained by weighing the weight of the filter paper before and after the experiment. Bridellia arthrourrides has the highest while Polyalthia longifolia has the lowest (figure 2). Saponins: The result for saponins was obtained using soxhlet extraction method where Bridella arthrourrides had the highest quantity while Allamanda cathartica has the lowest (figure 3).

Flavonoids: The result for flavonoid was drawn from the different stages of colour development in paper chromatography. The RF value was used in the calculation of flavonoids (Table 3 )

Conclusion: This research investigated the chemical compound (flavonoids, alkaloid, saponins and tannins) content of selected plant species. Flavonoids, tannins, saponins and alkaloids were detected in the sampled plant species in varying concentrations therefore, the utilization of these plant extracts for therapeutic purposes where applicable is advocated.

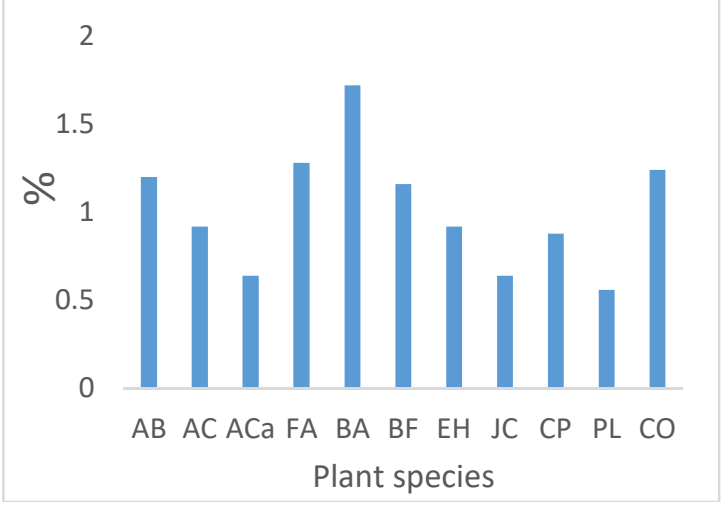

Fig 2: Percentage Alkaloids content of the eleven plant species evaluated $(\mathrm{AB}=$ Alstonia boone $; \mathrm{AC}=$ Alstonia congensis, $\mathrm{ACa}=$ Allamanda cathartica; $\mathrm{FA}=$ Funtumia africana $; \mathrm{BA}=$ Bridellia Artrourrides; $\mathrm{BF}=$ Bridellia Ferriginea $; \mathrm{EH}=$ Euphorbia hirta $; \mathrm{JC}$ $=$ Jatropha curcas $; \mathrm{CP}=$ Cleistophillis patens $; \mathrm{PL}=$ Polyalthia longifolia $; \mathrm{CO}=$ Canaga odorata $)$

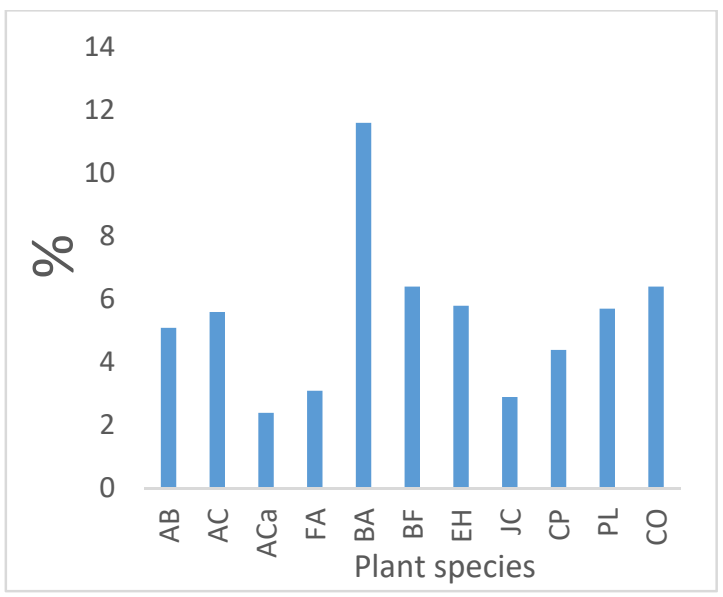

Fig 3: Percentage Saponins content of the eleven plant species evaluated $(\mathrm{AB}=$ Alstonia boone $; \mathrm{AC}=$ Alstonia congensis, $\mathrm{ACa}=$ Allamanda cathartica; $\mathrm{FA}=$ Funtumia africana $; \mathrm{BA}=$ Bridellia Artrourrides; $\mathrm{BF}=$ Bridellia Ferriginea $; \mathrm{EH}=$ Euphorbia hirta $; \mathrm{JC}$ $=$ Jatropha curcas $; \mathrm{CP}=$ Cleistophillis patens $; \mathrm{PL}=$ Polyalthia longifolia $; \mathrm{CO}=$ Canaga odorata)

Flavonoids were present in all eleven plant species studied some were more widely distributed than others and were found as mixtures. It is rare to detect pure flavonoid in the plant. Bridellia artrourrides, Funtumia africana, Canaga odorata and Alstonia boonei have high alkaloids. Bridellia artrourrides also recorded the highest saponin content while Alstonia boonei has the most elevated level of tannins among the plants investigated. The three plant families Apocyanaceae, Euphorbiaceae and Annonaceae have different levels of alkaloids, saponins and tannins content. 
Table 3: Result for flavonoid investigation

\begin{tabular}{|c|c|c|c|c|c|c|c|c|c|}
\hline & Taxa & Baw & Baw & Fores tal & fores tal & classes & Of & flavonoid & present \\
\hline & & $\mathrm{ff}(\mathrm{x} \mid 00)$ & colour & $r f(x 100)$ & colour & flavone & $\begin{array}{l}\text { glycosy1 } \\
\text { flavone }\end{array}$ & bioflavonyl & flavonol \\
\hline 1 & $\begin{array}{l}\text { Alstoria } \\
\text { boonei }\end{array}$ & 89.70 & Pale green & 77.8 & Orange & $\begin{array}{l}\text { Chrysoerion } \\
\text { Apigenin }\end{array}$ & & & \\
\hline 2 & $\begin{array}{l}\text { Alstonia } \\
\text { congersis }\end{array}$ & 92.12 & orange & 72.4 & Orange & Tricin & & kayaflavone & \\
\hline 3 & $\begin{array}{l}\text { Allamanda } \\
\text { cothartica }\end{array}$ & $89-09$ & purple & 69.5 & Orange & $\begin{array}{l}\text { Luteolin } \\
\text { Apignin }\end{array}$ & & & \\
\hline 4 & $\begin{array}{l}\text { Fiontumia } \\
\text { africana }\end{array}$ & 92.73 & purple & 71.8 & Purple & Tricin & & Kayaflavone & \\
\hline 5 & $\begin{array}{l}\text { Bridellia } \\
\text { artronerides }\end{array}$ & 93.33 & $\begin{array}{l}\text { Orange and } \\
\text { pale yellow }\end{array}$ & 71.2 & $\begin{array}{l}\text { Orange \& } \\
\text { bright } \\
\text { green }\end{array}$ & & Is ovitexin & & Qverecti: \\
\hline 6 & $\begin{array}{l}\text { Bridellia } \\
\text { ferriginea }\end{array}$ & 93.94 & Pale green & 76.0 & Orange & chrysoeriol & & kayaflavone & \\
\hline 7 & $\begin{array}{l}\text { Erphorbia } \\
\text { hirta }\end{array}$ & 36.97 & $\begin{array}{l}\text { Orange \& } \\
\text { pale yellow }\end{array}$ & 69.5 & $\begin{array}{l}\text { Orange \& } \\
\text { purple }\end{array}$ & orientin & Is ovitexin & & \\
\hline 8 & $\begin{array}{l}\text { Jatropha } \\
\text { curcas }\end{array}$ & 93.33 & purple & 70.0 & Orange & $\begin{array}{l}\text { Tricin } \\
\text { luteolin }\end{array}$ & & & \\
\hline 9 & $\begin{array}{l}\text { Cleistophilis } \\
\text { patens }\end{array}$ & 95.76 & Pale yellow & 71.2 & Orange & Tricin & & kayaflavon & \\
\hline 10 & $\begin{array}{l}\text { Polyalthia } \\
\text { longifolia }\end{array}$ & 96.97 & orange & 67.0 & Orange & luteoline & & kayaflavon & \\
\hline 11 & $\begin{array}{l}\text { Canaga } \\
\text { odorata }\end{array}$ & 98.79 & purple & 69.5 & Orange & Tricin & & kayaflavon & \\
\hline
\end{tabular}

\section{REFERENCES}

Alinor, LJ (2006). Preliminary photochemical and antimicrobial activity of Garcinia cola. J. Chem. Soc. Nig. 32(2): 41-47

Ayandele, A; Adebiyi, AO (2007). Antimimcrobial screening of extracts of Olax subscorpiodea. African Journal of Biotechnology, 6(7): 868-870

Blessy, BM; Suresh, KJ; Archana, T (2012). Phytochemical analysis of Citrus limonum pulp and peel. Int. J. Pharma. Pharma Sci., 4(2): 269 - 371

Davis, PH; Heywood, VH (1973). Principle of AngiospermTaxonomy. Robert, E Krieger Publishing Company, Huntington, New York. 234 pp.

Gayathri, V; Kiruba, D (2014). Preliminary Phytochemical Analysis of Leaf Powder Extracts of Psidium guajava L. Inter. J. Pharmacognosy and Phytochemical Res. $6(2), 332-334$

Harborne, JB (1973). Phytochemical methods: A guide to modern Technology of Plant Analysis. Chapman and Hall, London. 278 pp.

Harborne, JB (1984). Phytochemical methods II. Ed. In Chapman and Hall, New York. pp. 21 - 26.

Jack, IR.; Okorosaye-Orubite, K (2008). Phytochemical analysis and antimicrobial activity of the extract of leaves of fleabane (Conyzasum atrensis). J. Appl. Sci. Environ. Manage. 12 (4): 63-65.

Kumar, A; Ilavarasan, R; Jayachandran, T; Decaraman, M; Aravindhan, P; Padmanaban, N; Krishnan, MRV
(2009). Phytochemical investigation on a tropical plant. Pakistan Journal of Nutrition, 8(1): 83-85.

Moses, AG; Gatebe, E; Gitu, L; Rotich, H (2013). Preliminary phytochemical screening of eight selected medicinal herbs used for the treatment of diabetes, malaria and pneumonia in kisii region, Southwest Kenya.Eur. Journal of Applied Science, 5(1): 01-06.

Ogbeche, AK; Ajayi, GO; Onyenta, P (1997). Antimicrobial activities of the leaf extracts of Ageratum conyzoides. Nigeria Quarterly Journal of Hospital Medicine, 7: 397-399

Okerulu, IO; Ani, CJ (2001). The Phytochemical Analysis and Antibacterial screening of Extracts of Tetracarpidium conophorum. Journal of Chemical Society of Nigeria, 26 (1): 213-218

Parekh, J; Sumitra, CV (2007). Invitro antimicrobial activity and phytochemical analysis of some Indian Medicinal Plants. Turkish Journal ofs Biology, 31: 5358.

Perumal, SR; Gopala, KP (2007). Current status of herbal and their future perspectives, Nature Precedings, 11-76

Stace, C (1980). Plant Anatomy and Biosystematics. Edward arnold Publishers, London 279 pp

Uboh, FE; Okon, IE; Ekong, MB (2010). Effect of aqueous extract of Psidium guajava leaves on liver enzymes, histological integrity and hematological indices in rats. Gastroenterol. Res., 3(1): $32-38$. 